\title{
The Influence of Motivation, Needs, and Access to Information on Family Financial Planning in Life Insurance Purchasing
}

\author{
Istikhamah* \\ Department of Family and Consumer Sciences, \\ Faculty of Human Ecology, \\ Bogor Agricultural University
}

\author{
Lilik Noor Yuliati \\ Department of Family and Consumer Sciences, \\ Faculty of Human Ecology, \\ Bogor Agricultural University
}

*Corresponding author: istikhamah27@gmail.com

\begin{abstract}
Every human needs safety and security in which one does not feel worried in their life. The same thing happens within family. This entity should be able to manage of its material resources in order to achieve the future goals. One of the managerial tools is financial planning in life insurance purchasing as life insurance is a way to get security in family life. The study aimed to analyze the influence of motivation, needs, and information access on financial planning in life insurance purchasing within family. Participants were 84 family members, either husbands or wives who did family financial planning and were selected using simple random sampling technique. The data were collected by interview using structured questionnaires. The findings indicated that family with motivation and needs of safety and security was more likely to do financial planning in life insurance purchasing.
\end{abstract}

Keywords: financial planning, motivation, needs, number of information source, security

\begin{abstract}
Abstrak. Setiap manusia membutuhkan rasa aman dan kenyamanan dimana seseorang tidak merasa khawatir dalam hidupnya. Hal yang sama berlaku pada keluarga. Keluarga harus dapat mengatur sumber daya materi yang dimilikinya agar tercapai tujuantujuannya di masa mendatang. Salah satu cara pengaturannya ialah perencanaan keuangan dalam pembelian asuransi jiwa dimana asuransi jiwa merupakan suatu cara untuk mendapatkan rasa aman dalam kehidupan keluarga. Tujuan penelitian ini adalah untuk menganalisis pengaruh motivasi, kebutuhan, dan akses informasi terhadap perencanaan keuangan keluarga dalam pembelian asuransi jiwa. Partisipan dalam penelitian ini adalah 84 anggota keluarga, suami atau istri yang melakukan perencanaan keuangan keluarga dan ditentukan melalui teknik pengambilan contoh acak. Pengambilan data dilakukan dengan teknik wawancara menggunakan kuesioner terstruktur. Hasil penelitian menunjukkan bahwa keluarga dengan motivasi dan kebutuhan akan rasa aman dan nyaman lebih mungkin melakukan perencanaan keuangan keluarga dalam pembelian asuransi jiwa.
\end{abstract}

Kata kunci: jumlah sumber informasi, kebutuhan, motivasi, perencanaan keuangan, rasa aman 


\section{Introduction}

Human in their life will face a variety of possible risks. All these possibilities are uncertain in nature so that people need to minimize these risks with an appropriate action (Hartono, 1985). The existence of such uncertainty will encourage someone to reduce or share the risk by way of insurance. According to Nirmala (2002 ) to protect the future of the life insured risk in it, a family will typically invest part of their income.

The development of life insurance in Indonesia has decreased. Indonesian Life Insurance Association (AAJI) recorded in 2011, i.e. a total of 49.8 million people insured. Then in 2012, the rate has declined 8.12 percent to 45.7 million people ${ }^{1}$. Indonesia is a country which has been destroyed in an effort to protect against the human psyche. Based on the report Sigma World Insurance in 2012, total premiums Indonesia in 2011 amounted to 9.437 million dollars. Indonesia was ranked thirty, still four points below Singapore. There are still many people who believe that insurance is not important to have. Though life insurance is not a stranger to the people of Indonesia. According to Hartono (1985) it is associated with the persistence of the negative perception of the public about the existence of insurance.

Life insurance according to Purba (1992) based on an economic viewpoint is essentially a transfer of risk by the insured to the insurer that the financial losses suffered by the insured is guaranteed by the insurer. According to the Life Insurance Association of Indonesia (AAJI), life insurance is divided into a variety of products, that is: 1) Term is insurance that provides maximum protection with premiums which is relatively low, 2) Whole Life that is insuranced gives protection for life insurance, and 3) Endowment is an insurance protection that gives the sum insured when the insured dies within a specified period and at the same time give the entire sum insured if the insured is still alive at the end of the period of coverage . Endowment insurance type is divided into two types of Life Insurance Unit Linked Single and Regular Unit Link Insurance ${ }^{2}$.

Planning is a process that uses a cognitive ability to define what you will do (Deacon and Firebough, 1988). Planning has an important role in a family, especially financial planning. Financial planning is very important because it helps the family to live a life (Syarifuddin, 2012). With family finances, its management is expected to use the money in the family that can be an effective and efficient as needed so that families become prosperous families (Rodhiyah, 2012). Households must decide how to allocate their income over a period of time to maintain consumption levels constantly. Income levels vary during the life cycle, while household consumption is relatively continuous (Lee, Park, and Montalto, 2000).

The introduction of needs is essentially dependent on how many discrepancies between the present condition of consumers and the condition should be (Engel, Blackwell and Miniard, 1995)

\footnotetext{
${ }^{1}$ http://keuangan.kontan.co.id/news/jumlah-tertanggung-asuransi-jiwa-menurun

2 http://www.aaji.or.id/InfoCenter/Products.aspx
} 
Needs is a matter that must be met by the individual. One of them is the need for security. Safety need is a sense of physical protection needs. Physical needs will lead to obtaining a psychological sense of security because the consumer does not feel anxious and worried and threatened his life wherever he is (Sumarwan, 2011). The existence of these needs will drive an action called motivation. Such measures usually aim to meet customer satisfaction. Families who have the motivation to fulfill a sense of security for their families will encourage families to make a plan in the future.

One of the goals the family is getting the family's financial security and the fulfillment of a sense of security for their families in the future. One way to do for families in meeting these objectives is the purchase of life insurance. According to Nirmala (2002) the right way to overcome the financial risk individuals and families have an agreement with the insured or the insurer. The decision to purchase life insurance is an important decision (Goldsmith, 1983). Therefore, in deciding on the purchase of life insurance is important for families to perform an especially careful financial planning.

Life insurance is an important thing for a family in the fulfillment of feeling secure. As a family function is to provide protection to the security of other family members (Rice and Tucker, 1992). However, in general, the people of Indonesia have yet to put insurance as a priority to meet the need for security. This is due to a lack of information circulating in the community about the product and the important role of insurance (Hamidah 2006). Information is important in planning a purchase. Families would get information relating to products or services to be purchased from a variety of sources. According Sutisna (2001), this includes two sources of consumer information, which is a source of personal and impersonal sources. Information received by consumers can form a planning model that will be created. According to Erasmus, Boshoff, and Rousseau (2001) in the decisionmaking process, consumers can be educated or enhanced through the implementation of search behavior information needed to make good decisions. However, the more information is obtained, one or more problems will arise. Lack of information and awareness on the family in financial planning can lead a family experiencing difficulties that may be encountered later. According Guhardja et al. (1992) in making a budget of a family may be having difficulty so that it can start by looking for related information.

Based on the exposure, this study aimed to identify the motivations, needs, and access to the information on financial planning in the purchase of life insurance, identify financial planning in the purchase of life insurance, and analyze the influence of motivation, needs, and access to information on financial planning in purchasing life insurance.

\section{Literature Review}

Indonesia has a large population, but the number of users existing life insurance in Indonesia is still small. Total policyholder only reached 16.75 million or 0.07 percent of the total population of this country ${ }^{3}$. The existence of insurance

\footnotetext{
${ }^{3}$ http://nasional.kompas.com/read/2011/10/17/11211582/Mengenal.Asuransi.
} 
should be an important amid the lives of people who need protection from risk. However, lack of awareness of security needs, making many Indonesian people do not want to buy life insurance. The negative perception, lack of information and lack of knowledge of insurance will make many Indonesian people still do not want to make life insurance as a necessity for his family.

Planning is an important thing done by the family, especially financial planning. There are several factors that affect financial planning in the purchase of life insurance, the individual characteristics, family characteristics, motivations, needs, and access to information. The individual characteristics such as gender, age, length of education and employment, and family characteristics include a large family and total revenue per month. Each family has a financial planning course differently, because financial planning every family is unique. According Rodhiyah (2012) family financial planning is not generally applicable, but the specific nature was influenced by factors, among others: marital status, occupation, economic condition, age, and assets owned. In addition, the family life cycle stages (with age), experience, and education are other factors that affect planning (Deacon and Firebough, 1988).

Information received by consumers can form a planning model that will be created. According to Erasmus, Boshoff, and Rousseau (2001) in the decisionmaking process, consumers can be educated or enhanced through the implementation of search behavior information needed to make good decisions. Guhardja et al. (1992 ) states that in making a budget of a family, a person may have difficulty so that it can start by looking for information related.

\section{Participants}

\section{Methods}

Research conducted in Kebon Pedes, District Tanah Sareal, Bogor, West Java, Indonesia. The choice of location is done purposively on the grounds that the site has the most prosperous families in the city of Bogor. The population in this study is a secondary family with household expenditure per month is more than equal to Rp2.000.000. Examples in this study is a member of the family ( husband/ wife ) who do financial planning in the family. Random sampling was done by simple random sampling. The data of Basics Family in Kebon Pedes in 2012 recorded as many as 507 family has accumulated for more than equal to Rp2.000.000, so the total sample was taken as many as 84 people based on the following formula Slovin:

Where,

$$
\mathrm{n}=\frac{\mathrm{N}}{\left(1+\mathrm{Ne}^{2}\right)}=\frac{507}{1+507(0.1)^{2}}=83.52 \approx 84
$$

$\mathrm{n}=$ total

$\mathrm{N}=$ total population

$e=$ The critical value ( limit of accuracy for making mistakes population was set at $10 \%$ ) 


\section{Measurement}

The data used in this study are primary and secondary data. Primary data include respondent characteristics, family characteristics, motivations, needs, access to information, and financial planning. Primary data were obtained through a questionnaire with interview techniques. Meanwhile, secondary data research sites include the general conditions and the number of family welfare in Kebon Pedes in 2012 obtained by the Central Bureau of Statistics Bogor and Data Basic Family Kebon Pedes in 2012.

Characteristics of respondents consisted of gender, age, length of education, and type of work. Sex of the respondents are divided into male and female. The age of respondents was grouped in five categories (Sumarwan, 2004), that is, 1924 years (young adult), 25-35 years (middle age), 36-50 years (middle-aged), 5165 years (old), and over 65 years (elderly). Older respondents' education measured by long years of formal schooling is taken. This type of work can be divided into civil servants, private employees, TNI/ police, state enterprises, self-employed, housewives and others (pension and does not work). Characteristics include a large family and total family income per month. Large families is measured based on the number of family members who are divided into three categories (BKKBN, 1998), the family of small $(\leq 4)$, the family is (5-6 people), and a large family ( $\geq$ 7). Total family income per month was categorized into 1.000.000 - Rp2.000.000, Rp2.000.001 - 3.000.000, Rp3.000.001 - Rp5.000.000, Rp5.000.001 10.000.000, and over 10.000.000 (Kemendagri, 2012).

Motivation variable was measured using an instrument developed by researchers, consisting of five statements with the reliability value of 0.705 . Item statements are based on Maslow's hierarchy of motivation in which life insurance was included in the motivational sense of security and comfort. Measurements motivation to do with statements using a Likert scale consisting of four ranks $(1=$ strongly disagree, $2=$ disagree, $3=$ agree, $4=$ strongly agree). Scores were then classified into three categories defined by the following formula grade interval:

$$
\text { Class Interval }(I)=\frac{\text { Maximum score }- \text { Minimum score }}{\text { Amount of class }}
$$

Formula categories: low [(NR ) s.d $(\mathrm{NR}+\mathrm{I})]$, being [(NR+I)+1 s.d $(\mathrm{NR}+2 \mathrm{I})]$, high $[(\mathrm{NR}+2 \mathrm{I})+1$ s.d $(\mathrm{NT})]$. The maximum score of 20 and minimum 5, thus formed categories, that is : low (5-10), medium (11-15), and high (16-20).

Variable needs were measured to sort six statements based on the perception of respondents. Meanwhile, the data on access to information were collected using instruments belonging to the Putri (2012) which has been modified. This variable is measured by the number of respondent resources and the most trusted source of information respondents. The sources of the information include television, radio, magazines, newspapers, Leflet, posters, internet, life insurance agent, family, and friends/ neighbors. The amount of information is divided into four categories: 0 sources, 1-3 sources, 4-6 sources, and 7-10 sources. Each source is given a score of one. Family planning is measured through four-item scale statements $(1=$ strongly disagree, $2=$ disagree, $3=$ agree, $4=$ strongly agree). Respondents were 
asked whether they allocate money for the future and whether they have planned purchase life insurance for a long time.

\section{Analysis}

The data which have been collected are then processed and analyzed using Microsoft Excel and SPSS for Windows. The data analysis included descriptive and inferential analysis. The descriptive analysis which includes minimum and maximum values, average, standard deviation and percentage are used to identify individual characteristics of respondents and family characteristics. Inferential analysis used was multiple linear regression test. This test aims to analyze the influence of independent variables (the characteristics of respondents and family, motivation, needs, and access to information) on the dependent variable (financial planning ). To model the regression test, several variables are converted into dummy variables include gender $(1=$ female, $0=$ male $)$, employment status $(1=$ working, $0=$ not working $)$, needs $(1=$ the first order, $0=$ other $)$ and most trustworthy information source $(1=$ a life insurance agent, $0=$ other $)$.

\section{Results}

\section{Characteristics of Respondents and Family}

The number of respondents in this study was 84 people. A total of 46 respondents was male $(95.8 \%)$ and two of the respondents were female $(4.2 \%)$ whose status was as head of the family. This happens because there was one respondent whose husband had died and one respondent who did not married. A total of 36 respondents was female whose status was as the wife $(100 \%)$. A total of 34.5 percent of heads of household had a job as self-employed and more than half $(52.5 \%)$ and wife work as a housewife. A total of 39.3 percent of household heads was of old age (51-65 years), while the wife was as much as 42.5 percent of middle-aged (36-50 years). The average age of the head of the family and the wife was 48.23 years and 42.56 years, meaning that most of the heads of families and middle aged wife. The education of long head of the family and the wife who had the highest percentage in the range of 9.1 years to 12 years was 47.7 percent and 41.3 percent. The average length of education of head of the family and the wife was 13.51 years and 11.94 years, meaning that nearly head of the family and his wife graduated from high school. As many as 66.7 percent of respondents had a large family in the small family category with the average of four people. Large family indicated that there was at least one of the respondents who did not married. As many as 31 percent of respondents had total revenue in the range Rp2.000.001 - Rp3.000.000 and Rp5.000.001 - Rp10.000.000 with the average incomes of Rp6.410.119,05

\section{Access to Information}

As illustrated in Table 1, the majority of respondents $(71.4 \%)$ received information on life insurance from one to three sources. Less than 20 percent of respondents had four to five resources while the rest had never received information about life insurance from any source. Meanwhile, more than half of respondents $(59.5 \%)$ stated that life insurance agent was is source of reliable 
information. This was understandable because life insurance agents are professionals who are trained to provide the most accurate information about the benefits, how to calculate premiums, and other detailed information so that consumers will feel confident in doing financial planning to buy life insurance.

Table 1 The distribution of respondents by the number of resources and a source of reliable information

\begin{tabular}{|c|c|c|}
\hline Variable & $\mathrm{N}$ & $\%$ \\
\hline \multicolumn{3}{|c|}{ The amount of resources } \\
\hline 0 source & 8 & 9.5 \\
\hline 1-3 source & 60 & 71.4 \\
\hline 4-6 source & 15 & 17.9 \\
\hline $7-10$ source & 1 & 1.2 \\
\hline Total & 84 & 100.0 \\
\hline Min-max & \multirow{2}{*}{\multicolumn{2}{|c|}{$\begin{array}{c}0-9 \\
2.26 \pm 1.64\end{array}$}} \\
\hline Average $\pm \mathrm{SD}$ & & \\
\hline \multicolumn{3}{|c|}{ Source of information } \\
\hline Not informed & 8 & 9.5 \\
\hline Television & 4 & 4.8 \\
\hline Radio & 0 & 0.0 \\
\hline Magazines & 0 & 0.0 \\
\hline Newspapers & 1 & 1.2 \\
\hline Leflet & 1 & 1.2 \\
\hline Posters & 0 & 0.0 \\
\hline Internet & 1 & 1.2 \\
\hline Life insurance agent & 50 & 59.5 \\
\hline Family & 5 & 5.9 \\
\hline Friend/ neighbors & 14 & 16.7 \\
\hline Total & 84 & 100.0 \\
\hline
\end{tabular}

\section{Family Financial Planning}

In terms of family financial planning, respondents were asked to rank the approval of two statements: allocate some of the money for planning in the old days and the purchase of life insurance planned long ago. The results showed that more than half of respondents $(53.6 \%)$ agreed to their first statement. This means that the respondent has had financial planning for the future, especially for retirement. However, there are still the respondents (11.9\%) are not planning to. A similar proportion (52.4\%) was known to have planned the purchase of life insurance for a long time, indicating awareness of the importance of having life insurance as protection.

\section{Motivation}

Based on Maslow's theory, life insurance included in the hierarchy of motivation a sense of security and comfort. There is a five-item statements scored by a scale of 4 from strongly agree to strongly disagree. More than half of respondents $(59.6 \%)$ disagreed with the statement that the purchase of life insurance guarantees reduces financial risk. However, a similar proportion $(59.5 \%)$ believe that the life insurance can reduce future losses suffered by the family. Respondents stated that they are motivated to purchase life insurance to 
reduce the burden of the family in the future $(67.9 \%)$, to provide protection for the family $(88.1 \%)$, and to get a guaranteed security in the future $(79.8 \%)$.

In order to get a better understanding in terms of motivation of respondents in the purchase of life insurance, this construct is divided into three levels including low, medium and high based on the scores of respondents. As shown in Table 2, the motivation of the majority of respondents $(82.1 \%)$ was categorized at level while the rest was scattered at low level and high.

Table 2 The distribution of respondents by category of motivation

\begin{tabular}{lcc}
\hline Category & $\mathrm{n}$ & $\%$ \\
\hline Low $(5-10)$ & 4 & 4.8 \\
Medium (11-15) & 69 & 82.1 \\
High (16-20) & 11 & 13.1 \\
\hline Total & 84 & 100.0 \\
Min-maks & & $10-20$ \\
Average \pm SD & \multicolumn{2}{c}{$13.89 \pm 2.134$} \\
\hline
\end{tabular}

\section{Need}

Table 3 shows the total 21 respondents $(25 \%)$ who chose the statement of life insurance to guarantee family life in the future as the first in the life insurance needs. Then the second in a statement that needs life insurance to have security in life with a total of 18 respondents $(21.4 \%)$.

Table 3 The distribution of respondents by the response to the questionnaire needs

\begin{tabular}{lcc}
\hline Statement & $\mathrm{n}$ & $\%$ \\
\hline Guarantee family life in the future & 21 & 25.0 \\
To get the security in life & 18 & 21.4 \\
To share the risks to be faced later & 14 & 16.7 \\
In order to guarantee financial security in the future & 7 & 8.3 \\
For a sense of belonging among fellow members of the family & 5 & 5.9 \\
To improve the economic status of the family & 4 & 4.7 \\
\hline
\end{tabular}

\section{Factors that Influence Family Financial Planning in Purchasing Life Insurance}

Table 4 shows that the variables that affect the family's financial planning in purchasing life insurance is the motivation $(\mathrm{B}=0.233 ; \mathrm{p}$-value $=0.000)$ and the need for security $(\mathrm{B}=0701 ; \mathrm{p}$-value $=0.024)$. The results of multiple regression analysis showed that these two variables affect financial planning in the purchase of life insurance in a positive way. The regression coefficient for the motivation variable is 0.233 , which means if the motivation of families has increased a unit, then a financial planning will also increase by 0.233 . The regression coefficients for the variables safety need is 0.701 , which means if the need for security has increased the family unit, the family financial planning will also increase by 0.701 . The results show the value of Adjusted R square of 0.303 . This means that as many as 30.3 percent of financial planning in the purchase of life insurance is influenced by the ten independent variables which were researched. The remaining 69.7 percent of the dependent variable is influenced by other variables that are not in thoroughly. 
Tabel 4 Factors that influence family financial planning in purchasing life insurance

\begin{tabular}{lcc}
\hline \multirow{2}{*}{ Variable } & \multicolumn{2}{c}{ Family financial planning in purchasing life } \\
& \multicolumn{2}{c}{ insurance } \\
\cline { 2 - 3 } & $\mathrm{B}$ (Unstandardize) & Sig. \\
\hline Constanta & 0.992 & 0.514 \\
Gender (0: male; 1:female) & 0.198 & 0.466 \\
Long education (years) & 0.057 & 0.351 \\
Employment status (0: no work; 1: work) & 0.513 & 0.068 \\
Age (years) & -0.012 & 0.277 \\
Large families (people) & -0.009 & 0.934 \\
Revenue per month (IDR) & $4.079 \mathrm{E}-8$ & 0.142 \\
Motivation (score) & 0.233 & $0.000^{* *}$ \\
Need for security (0: not the first order; 1: the & 0.701 & $0.024^{*}$ \\
first order) & & 0.587 \\
Total resource (source) & 0.039 & 0.496 \\
The most trusted source of information (0: & -0.167 & \\
other than life insurance agents; 1: life & & \\
insurance agent) & \multicolumn{2}{c}{4.602} \\
\hline F & \multicolumn{2}{c}{0.387} \\
R square & \multicolumn{2}{c}{0.303} \\
Adj R square & & \\
\hline
\end{tabular}

Note. $(* *)$ significant on $\mathrm{p}$-value $<0.01 ;(*)$ significant on $\mathrm{p}$-value $<0.05$

\section{Discussion}

Human beings in each of their lives will face uncertainty. Therefore, human life requires a sense of security and comfort. Maslow express five human needs based on the level of importance (Sumarwan, 2011). Safety need is a physical protection need. Physical needs will lead to the acquisition of a psychological sense of security because the consumer does not feel anxious and worried and threatened his life wherever he is (Sumarwan, 2011). One way to meet the need for security is participating in life insurance. According to Thakkar (2012) life insurance is a mean of protection against the human psyche, basically for protection from sudden death.

The results showed 48 respondents $(57.1 \%)$ had a status as head of household and 36 respondents $(42.9 \%)$ had status as a wife. Family financial planning should not be done by a wife, but a husband can do it. A total of 34.5 percent of heads of household has a job as self-employed and more than half $(52.5 \%)$ and wives work as a housewife. Sumarwan (2004) differentiated according to age category, that is early adulthood, middle age, middle-aged, old, and elderly. A total of 39.3 percent of household heads of old age (51-65 years), while the wife as much as 42.5 percent of middle-aged (36-50 years). The average age of the head of the family and the wife is 48.23 years and 42.56 years, which means most of the heads of families and middle aged wife. Purba (1992) found the age of 20 years to 55 years is the target life insurance protection and already have economic value life. Therefore, it is important for families to start planning financially in the purchase of life insurance to have security in the future. The education of long head of the family and the wife had the highest percentage in the range of 9.1 years to 12 years that is equal to 47.7 percent and 41.3 percent. 
The average length of education of head of the family and the wife is 13.51 years and 11.94 years, which means nearly head of the family and his wife graduated from high school. High levels of education tend to encourage someone to do things that can provide protection to his family, so that they will plan financially in the purchase of life insurance. This is according to Truett and Truett (1990) that the higher education level was associated with a strong desire to protect and maintain the standard of living of their dependents. Factors of education has an important role in increasing interest in family financial planning (Yohnson, 2004).

As many as 66.7 percent of respondents are in the small family category with the average of four people. For a family, the child is certainly an investment whose needs to be guarded and protects his future. According Senduk (2001) when a person is married and has children, families may have to anticipate the risks that may occur in the family. A family needs to make family financial planning, especially in the purchase of life insurance in anticipation of bad possibilities that will happen in a family. As many as 31.0 percent of respondents had total revenue in the range of $\mathrm{Rp} 2.000 .001-3.000 .000$ and $\mathrm{Rp5.000.001-}$ 10.000.000. Each family would have an income that is different, but the need for security is always needed by anyone. Therefore, it is important for families to be able to manage earnings in order to achieve a long-term planning purposes, namely life insurance. According Lock (1971) life insurance is generally used by each consumer at every level of income with a variety of needs and situations. When viewed from the income per capita by BPS (GK West Java, 2012) as much as 98.8 percent of respondents in the category is not poor because the per capita income is of more than Rp417.795.

Information is one of the important things needed in planning a purchase. In life, the family has received information from various sources. Information on the life insurance covers benefits and how the calculation of premiums. In this study, the majority of respondents has a source of information from one to three sources of information (71.4\%). Then as many as 17.9 percent of respondents has the resources as much as four to six resources. In planning, financial planning, in particular in the purchase of life insurance, the family should be active in seeking information. When viewed from the value of the average amount of resources, then the average respondent only to get information from one to two sources. According Çelik and Kayali (2009) many consumers may avoid buying life insurance because they do not have information about this process.

Life insurance agents is the largest selection (59.5\%) as the most trustworthy source of information that is selected by respondents in providing information about life insurance on the benefits and how the calculation of premiums. Life insurance agent is one source of information that is selling face to face. According Sutisna (2001) face to face sales have advantages compared to other promotional tools for dealing directly with potential customers. Life insurance agent plays an important role in providing direction, advice, and feedback in helping respondents to plan financial in the purchase of life insurance. According Berutu (2010) insurance and financial planning is as simple as requiring any assistance and consultation from a professional insurance agent. There are still many people who think negatively about the role and importance of life insurance, so that people do not want to plan financially in the purchase of life 
insurance. Therefore, it takes an important role of life insurance agent to attract consumers in financial planning in the purchase of life insurance. According to Nirmala (2002) life insurance agents have a significant impact on the family's perception about life insurance.

Financial planning done by the family is very important because the the family can control any of their family's financial allocation. According to Warsono (2010) it is guaranteeing financial security and the anticipation of a large loss in the future, both from the loss of life and the wealth of the family members need to be done. According to Bertisch (1994) in Yohnson (2004) financial planning can be interpreted as preparation or coordination cautious plan in order to prepare the desires and financial goals in the future. Family financial planning in the purchase of life insurance is one of the preparations that can be done as early as possible to face a future filled with uncertainty.

Family financial planning is the process of allocating the family finances to achieve financial goals $\mathrm{i}$ a short and long term. The results showed that as many as 42.9 percent of respondents said that they did not agree on a statement of life insurance purchases planned long ago. Life insurance is a necessary and important for a family to be planned. It is very important for the customer to do financial planning. According Sembel, Ichsan, and Lopez (2003) one of the reasons why financial planning needs to be done by the family to protect yourself and family from a variety of financial risks that get the impact. Families should be able to set aside some of their earnings for life insurance. But according Hardianto (2012) lack of public investment is more due to the tendency of people who do not understand insurance ${ }^{4}$. Insurance should not be seen as a burden on the financial resources, if someone is able to plan your finances well ${ }^{5}$.

The family certainly has the financial goals for later old age. To achieve financial goals, one needs a financial plan (Senduk, 2001). The results show as much as 53.6 percent of respondents agreed to the statement of allocating part of the money for retirement plans. One of the financial goals a family want to achieve was preparing for retirement (age days old ). According to Deacon and Firebough (1988) in anticipation of the future is an important part of a plan. Good financial planning and balance in towards financial success will also help to prevent the financial crisis (Kenyon and Borden, 2004). Life insurance can be used as well as the way in which the family in the face of financial risk in the future. According to Wang and Rosenman (2007), life insurance is an effective tool to reduce the financial risk.

Motivation is a driving force that will compel individuals to act (Schiffman and Kanuk, 1983). The results showed as many as 82.1 percent of respondents have motivated the medium category. This means that most of the respondents have a motivation that is in the purchase of life insurance. As many as 13.1 percent of respondents have a motivation in the high category and only 4.8 percent of respondents have the motivation in the low category. According Setiadi (2010) that the motivation has elements that needs, goals and efforts . Their

\footnotetext{
${ }^{4}$ http://www.harianterbit.com/2012/12/20/10560/

${ }^{5}$ http://lipsus.kompas.com/cerdasberasuransi/read/2012/10/25/1255043/Kesenjangan.Perlindungan.dan.Kekeli ruan.Persepsi.
} 
motivation will encourage families to strive financial plan and achieve these objectives, namely the purchase of life insurance.

Needs is a matter that must be met in order to achieve the satisfaction of the consumers themselves. The statement needs life insurance to guarantee family life in the future got the largest selection as the first order in the variable needs by 25 percent. Then the second in a statement that the needs of life insurance need to have security in life with a total of 18 respondents $(21.4 \%)$. This means that life insurance is not only just meet the safety needs but also to guarantee the life of the family.

One of the important decisions for an individual or family is to buy insurance or not (Çelik and Kayali, 2009). The results showed that the variables that affect the family's financial planning in purchasing life insurance is the motivation $(B=0.233$; $p$-value $=0.000)$ and the need for security $(B=0701$; $p$ value $=0.024$ ). Both of these variables influence the family financial planning in the purchase of life insurance in a positive way. The regression coefficient for the motivation variable is 0.233 , which means if the motivation of families has increased a unit, then a financial planning will also increase by 0.233 . In planning something, especially the purchase of life insurance will certainly have the motivation perceived beforehand. The motivation felt by respondents is the feeling of security and comfort so that when respondents have a high motivation to have security sense, they will plan their finance to purchase life insurance.

Life insurance is one way that families can do to reduce the losses that will occur in the future so that the family will feel safei in their life. The regression coefficients for the variables safety need is 0.701 , which means if the need for security has increased the family unit, the family financial planning will also increase by 0.701 . One way that can be done by the family in meeting security needs are participating life insurance. When the need for security in a family increases, then the family will plan financially in the purchase of life insurance. The results show that the value of Adjusted $\mathrm{R}$ square is of 0.303 . This means that as many as 30.3 percent of financial planning in the purchase of life insurance is influenced by the ten independent variables were researched, the remaining 69.7 percent of the dependent variable is influenced by other variables that are not in thoroughly.

\section{Conclusions}

\section{Conclusions and Suggestions}

The study involved 84 people from 84 different families. A total of 48 respondents has status as the head of household and 36 respondents have status as a wife. The work as self-employed is mostly performed by the head of a family with a percentage of 30.9 percent. Most of the heads of the family and the wives of middle-aged (35-50 years) with an average age of head of household and the wife of the respondents are 48.23 years and 42.56 years. Old head of the family education and wife both had the highest percentage in the range of 9.1 years to 12 years is 47.7 percent and 41.3 percent. The average length of education of head of the family and the wife is 13.51 years and 11.94 years, which means nearly head of the family and his wife completed secondary education upon it. As many as 
66.7 percent of respondents included in the category of small family with the average four-member family. As many as 31 percent of income ranges Rp2.000.001 - 3.000.000 and Rp5.000.001 - 10.000.000.

Most respondents have a source of information from one to three sources with a percentage of 71.4 percent. Then as many as 17.9 percent of respondents have the resources as much as four to six resources. Life insurance agents into the most trusted source of information that has been chosen by the respondent. As many as 42.9 percent of respondents said that they did not agree on a statement of life insurance purchases planned long ago. But as many as 53.6 percent of respondents agreed to the statement of allocating part of the money for retirement plans. Most respondents have motivated the medium category. As many as 13.1 percent of respondents has a motivation in the high category and only 4.8 percent of respondents who has the motivation in the low category. Life insurance needs to ensure the future of family life got the largest selection as a first order of 25 percent. Then the second order is the statement of life insurance need to get safety in life". This was chosen by 21.4 percent. Motivation and safety needs affect the family financial planning to purchase life insurance positively.

\section{Suggestions}

Life insurance agent is a source of information that is the most preferred by respondents. Life insurance companies should conduct training on a life insurance agent to make it more attractive, could be more credible and convincing consumers to help plan their finances in the purchase of life insurance. Government must provide information or appeal of the role and importance of life insurance for people's lives and the future of the program on how to plan family finances properly, so that people will put it into practice in daily life. Society at large is expected to be more positive thinking, and many are looking for information about the role and importance of life insurance for life. More can set family financial planning for purpose in the future and given the understanding that life insurance is essential for life in the future so that it can do a financial planning in the purchase of life insurance since the beginning.

\section{Reference}

Berutu, E. K. (2010). Importance of Financial Security. Regarding Indonesia. Finance: insurance Column editorial cooperation around Indonesia-AAJI (17).

Çelik, S., \& Kayali, M. M. (2009). Determinants of demand for life insurance in European countries. Problems and Perspectives in Management, 7 (3), 3237. Available

on http://businessperspectives.org/journals_free/ppm/2009/PPM_EN_2009_03 Celik.pdf

Deacon, R. E., \& Firebough, F. M. (1988). Family Resources Management Principles and Application (Issue 2). Boston, MA: Allyn and Bacon. 
Engel, J. F., Blackwell, R. D., \& Miniard, P. W. (1995). Consumer Behavior (Volume 1 Issue 6). Budiyanto, translator. Jakarta, Indonesia: Binarupa Script.

Erasmus, A. C., Boshoff, E., \& Rousseau, G. G. (2001). Consumer decision making models within the discipline of consumer science: A critical approach. Journal of Family Ecology and Consumer Science, 29, 82-90. doi: 10.4314 / jfecs.v29i1.52799

Goldsmith, A. (1983). Household life cycle protection: Human capital versus life insurance. The Journal of Risk and Insurance, 50, 33-45. doi: 10.2307 / 252 438.

Guhardja, S., Puspitawati, H., Hartayo \& Hastuti, D. (1992). Family Resource Management diktat. Bogor, Indonesia: Bogor Agricultural University.

Hamidah, N. (2006). Analysis of the perception of the policyholder 1912 on the effectiveness of personal selling (Case Study operational offices Siliwangi) (Thesis). Available on http://repository.ipb.ac.id/bitstream/handle/123456789/10457/H06nha.pdf?s equence $=3 \&$ is Allowed $=y$.

Hartono, S. R. (1985). Insurance and Insurance Law in Indonesia. Semarang, Indonesia: Teachers' Training College Semarang Press.

Kenyon, D. Y. B., \& Borden, L. M. (2004). Family financial management Planning for the future (Promoting the health and well-being of families during difficult, times). Available on http://extension.arizona.edu/sites/extension.arizona.edu/files/pubs/az1341i.p df.

Lee, S., Park, M. H., \& Montalto, C. P. (2000). The effect of family life cycle and financial management practices on household saving patterns. Journal of Korean Home Economic Association English Edition, 1 (1), 79-93. Available

on http://ocean.kisti.re.kr/downfile/volume/khea/E1HEAZ/2000/v1n1/E1HEA Z_2000_v1n1_79.pdf.

Lock, L. H. (1971). Household Saving in West Malaysia and the Problem of Financing Economic Development. Kuala Lumpur, Malaysia: Faculty of Economic and Administration, University of Malaya

Nirmala, I. R. (2002). Factors that influence the decision-making families participated in life insurance (Thesis). Available on http://repository.ipb.ac.id/bitstream/handle/123456789/17361/A02irn.pdf?se quence $=2$ \&is Allowed $=y$.

Purba, R. (1992). Understanding Insurance in Indonesia. Jakarta, Indonesia: PT. Reader Binaman Pressindo.

Putri, A. M. L. (2013). Access to information, knowledge, risk perception and intention of the use of contraceptives. Journal of Family and Consumer Sciences, 6 (3), 199-205. Available on http://journal.ipb.ac.id/index.php/jikk/article/view/9988/7810.

Rice, A. S., \& Tucker, S. M. (1986). Family Life Management (Issue 6). New York, NY: Harper Collins College Publishers. 
Rodhiyah. (2012). Family financial management in order to lead a prosperous family. Forum: Journal of Development Studies, 40 (1), 28-33. Available on http://ejournal.undip.ac.id/index.php/forum/article/view/3202/2875.

Schiffman, L. G., \& Kanuk, L. L. (1983). Consumer Behavior (Issue 2). New Jersey, NJ: Pretince Hall co.

Sembel, R., Ichsan, M., \& Lubis P. (2003). Smart Saving and Borrowing for Ordinary Family. Jakarta, Indonesia: Elex Media Komputindo.

Senduk, S. (2001). Managing the Family Financial. Jakarta, Indonesia: PT. Elex Media Komputindo.

Setiadi, N. J. (2010). Consumer Behavior (Contemporary Perspectives on Motive, Interest and Desire Consumers). Jakarta, Indonesia: Kencana Prenada Media Group.

Sumarwan, U. (2004). Consumer Behavior: Theory and Practice in Marketing. Bogor, Indonesia: PT Ghalia Indonesia.

2011. Consumer Behavior: Theory and Practice in Marketing. Bogor, Indonesia: Ghalia Indonesia.

Sutisna. (2001). Consumer Behavior and Marketing Communications. Bandung, Indonesia: PT Youth Rosdakarya.

Swiss Reinsurance Company Ltd. (2012).World Insurance in 2011. Zurich: Swiss Re.

Syarifuddin, H. (2012). Analysis of financial management, economic stress, coping strategies and the welfare of fishermen families in the village Cikahuripan, Cisolok subdistrict, Sukabumi (Thesis). Available on http://repository.ipb.ac.id/handle/123456789/54401.

Thakkar, D. K. (2012). A study of consumer behavior towards life insurance in Kolhapur City. Golden Thoughts and Research, 2 (1).

Truett, D. B., \& Truett L. J. (1990). The demand for life insurance in Mexico and the United States: A comparative study. The Journal of Risk and Insurance, 57, 321-328. http://dx.doi.org/10.2307/253306.

Wang, H. H., \& Rosenman, R. (2007). Perceived and actual need for health insurance demang Among Chinese rural resident. China Economic Review, 18 (4), 373-388. doi: 10.1016 / j.chieco.2006.11.002.

Warsono. (2010). The principles and practices of personal finance. Salam, 13 (2), 137-151. Available on http://ejournal.umm.ac.id/index.php/salam/article/view/470/477.

Yohnson. (2004). The role of universities in Surabaya in increasing the number of settled families in Surabaya (Family Financial Research Series). Journal of Management and Entrepreneurship, 6 (1), 54-71. Available on http://jurnalmanajemen.petra.ac.id/index.php/man/article/view/15649/15641

Yuliati, L. N. (2008). Influence purchasing behavior and consumption of milk and nurturing the growth and development of children aged 2-5 years in the city of Bogor (dissertation). Available on http://repository.ipb.ac.id/bitstream/handle/123456789/41016/20081ny.pdf?s equence $=11 \&$ is Allowed $=\mathrm{y}$. 